\author{
О.Б. Леонтьєв, М.В. Науменко
}

Харківський начіональний університет Повітряних Сил ім. І. Кожедуба, Харків

\title{
МЕТОДИКА ПРОГНОЗУВАННЯ ВАРТОСТІ ЖИТТЕВОГО ЦИКЛУ ПАРКІВ АЛЬТЕРНАТИВНИХ ТИПІВ НОВИХ БАГАТОЦІЛЬОВИХ ЛІТАКІВ, ЯК ОСНОВНИХ НОСІЇВ БОЙОВИХ СПРОМОЖНОСТЕЙ ТАКТИЧНОЇ АВІАЦІЇ
}

При формуванні довгострокових програм розвитку системи озброєння та військової техніки тактичної авіації Повітряних Сил Збройних Сил України, щзо має здійснюватися на основі формалізованих критерії типу “ефективність - вартість - час", однією із важливих складових є прогнозування фінансових витрат на закупівлю та постачання у війська необхідної кількості багатоцільових літаків тактичної авіації, а також витрат на забезпечення відповідним озброєнням, на утримання відповідної інфраструктури на всьому періоді їх експлуатації та на здійснення заходів інженерно-авіаційного забезпечення. Представлена методика прогнозування вартості життєвого циклу парків багатоцільових літаків спрямована на забезпечення коректного формування системи обмежень у математичній задачі оптимізачіі для синтезу раціональної програми розвитку системи озброєння та військової техніки тактичної авіації Повітряних Сил Збройних Сил Украӥни. Розроблена методика прогнозування вартості життєвого ичиклу парків багаточільових літаків, які розглядаються як основні носії бойових спроможностей тактичної авіації Повітряних Сил Збройних Сил Украӥни, трунтується на використанні залежності ціни серійних тактичних літаків на світовому ринку озброєнь від значень узагальнених показників їх бойових властивостей. Особливістю методики, щчо пропонується, є врахування вартості життєвого ичиклу парків альтернативних типів багатоиільових літаків тактичної авіації в залежності від того, чи є літаки, щзо плануються до постачання у бойові частини розробленими та виробленими всередині країни, або будуть закуплені за імпортом. Це вносить відмінності у типовий розподіл вартості по стадіях та етапах життєвого цииклу бойової авіаційної техніки, які повинні бути врахованими. Також представленою методикою передбачено врахування зміни витрат на експлуатацію бойових літаків, термін експлуатації яких перевищуватиме 15 років.

Ключові слова: планування на основі спроможностей, науково-методичний апарат, життєвий цикл авіаційної техніки, типовий розподіл вартості життєвого ичиклу, система озброєння тактичної авіації Повітряних Сил Збройних Сил Украӥни.

\section{Вступ}

Постановка проблеми. Актуальність оцінювання вартості життєвих циклів носіїв спроможностей обумовлено системною єдністю розвитку спроможностей Повітряних Сил (ПС) Збройних Сил (3С) України з економічними можливостями держави щодо забезпечення набуття необхідного рівня спроможностей у виконанні завдань відповідно до можливих сценаріїв застосування ПС ЗС України, які наведені у Каталозі спроможностей Міністерства оборони України, Збройних Сил України та інших складових сил оборони (далі Каталог) [1]. Відповідно до Рекомендацій з оборонного панування [2], одним із шляхів набуття спроможностей $є$ розвиток відповідних носіїв спроможностей. Основними типами носіїв бойових спроможностей тактичної авіації, які визначені у Каталозі [1], є літаки тактичної авіації та парки бойових літаків авіаційних частин і підрозділів. Оскільки дефіцит спроможностей тактичної авіації Повітряних Сил Збройних Сил Украї- ни обумовлюється моральним та фізичним старінням існуючого парку бойових літаків [3], методичні дослідження щодо забезпечення реалізації своєчасних заходів із закупівлі та постачання у війська необхідної кількості літаків тактичної авіації та забезпечення їх експлуатації на всьому періоді їх термінів служби набувають підвищеної актуальності. При цьому, ключовою задачею при оцінюванні альтернативних типів багатоцільових тактичних літаків, які можуть розглядатися для закупівлі в інтересах ПС ЗС України, є оцінювання як бойових спроможностей альтернативних типів літаків, так i прогнозування фінансової складової можливих угод щодо закупівлі та експлуатації оновлених парків тактичних літаків для виваженого та грунтовного запиту у бюджет держави. Тобто, складовими таких досліджень має бути оцінювання не лише вартості літаків тактичної авіації на світовому ринку озброєння, а, що не менш важливо, - оцінювання можливих фінансових витрат на їх експлуатацію, створення запасів авіаційних засобів ураження, всебічне 
забезпечення та утримання відповідної інфраструктури. Світовий досвід свідчить, що витрати на закупівлю систем озброєння та військової техніки (ОВТ) в кілька разів нижче, ніж витрати на подальшу їх експлуатацію та технічне супроводження. Особливо це актуально для систем ОВТ, строки експлуатації яких становлять 20-30 років [4-6].

Таким чином, розробка відповідного методичного забезпечення прогнозування вартості окремих стадій, а іноді і етапів життєвого циклу багатоцільових літаків тактичної авіації, які можуть розглядатися як альтернативні для закупівлі з метою набуття необхідних спроможностей тактичною авіацією ПС 3С України, є актуальною та важливою для практики оборонного планування задачею.

Аналіз останніх досліджень і публікацій. Головною метою проведення досліджень щодо фінансового оцінювання можливих витрат державного бюджету у разі закупівлі парку тактичних літаків того або іншого альтернативного типу при формуванні програм розвитку ОВТ тактичної авіації ПС ЗС України є надання адекватної інформації не лише про оцінки вартості літаків, а також і прогнозні дані про фінансові зобов'язання щодо експлуатаційних витрат на протязі періоду їх застосування за призначенням.

Для оцінювання вартісних показників носіїв спроможностей може застосовуватися поняття типового життєвого циклу (ЖЦ) бойової авіаційної техніки та типового розподілу його вартості по основних стадіях та етапах, що являє собою основний інструмент щодо оцінювання прогнозних значень вартості етапів ЖЦ зразків бойової авіаційної техніки [7-10].

Наявність типового розподілу вартості ЖЦ бойових літаків по основних стадіях та етапах дозволяє визначити залежність між вартістю серійного зразка бойової авіаційної техніки та витратами на стадію використання його за призначенням, якщо на протязі реалізації останньої будуть здійснюватися у повному обсягу всі види робот по експлуатації та ремонту авіаційної техніки, а також бойова підготовка особового складу стройових частин буде відповідати умовам, при яких визначався типовий розподіл вартості ЖЦ бойових літаків. Таку залежність можливо отримати, якщо покласти, що загальні витрати ресурсів у коштовно-грошовому вигляді на розробку та підготовку серійного виробництва літаків даного типу, які випадають на один літак з розрахункової серії літаків даного типу (запланованого обсягу серійного виробництва), та витрати на окремо взятий літак в цій серії складають загальну ціну серійного літака. Таке припущення співпадає із загальною схемою формування ціни на бойові літаки та не протирічить світовому досвіду укладання міжнародних угод щодо імпорту бойової авіаційної техніки [7].
За результатами проведеного аналізу встановлено, що $є$ певні відмінності у розподілу вартостей типового життєвого циклу бойової авіаційною техніки. Це обумовлюється тим, чи є літаки, що закуповуються для постачання у бойові частини розробленими та виробленими всередині країни, або $\epsilon$ такими, що закуповуються за імпортом.

Типовий розподіл вартості життєвого циклу бойової авіаційної техніки, розроблення та виробництво якої проходило всередині країни, для озброєння збройних сил якої вони призначалися, наведено на рис. $1[2 ; 11]$.

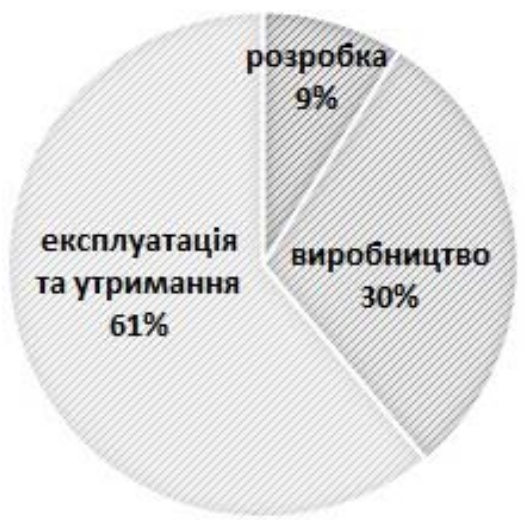

Рис. 1. Типовий розподіл вартості по основних стадіях ЖЦ бойової авіаційної техніки, створеної всередині країни Джерело: [2; 11].

Для країн-імпортерів військової техніки типовий розподіл витрат за окремими стадіями ЖЦ літаків тактичної авіації має декілька інший вигляд, який наведено на рис. 2. Детальний аналіз доступних даних щодо укладених угод про імпорт бойової авіаційної техніки свідчить про незначні відхилення у розподілі вартості за основними стадіями ЖЦ, що розглядається, та не перевищує 5\% [4; 12-23].

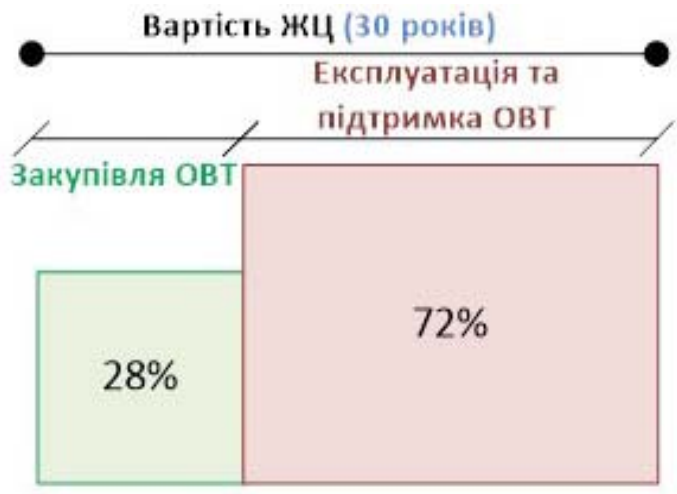

Рис. 2. Типовий розподіл вартості по основних стадіях ЖЦ бойової авіаційної техніки, що поставляється за імпортом Джерело: [4; 12-13].

Типовий розподіл витрат по складових вартості ЖЦ бойової авіаційної техніки на стадії ії експлуатації наведено на рис. 3 [13; 24-25]. 


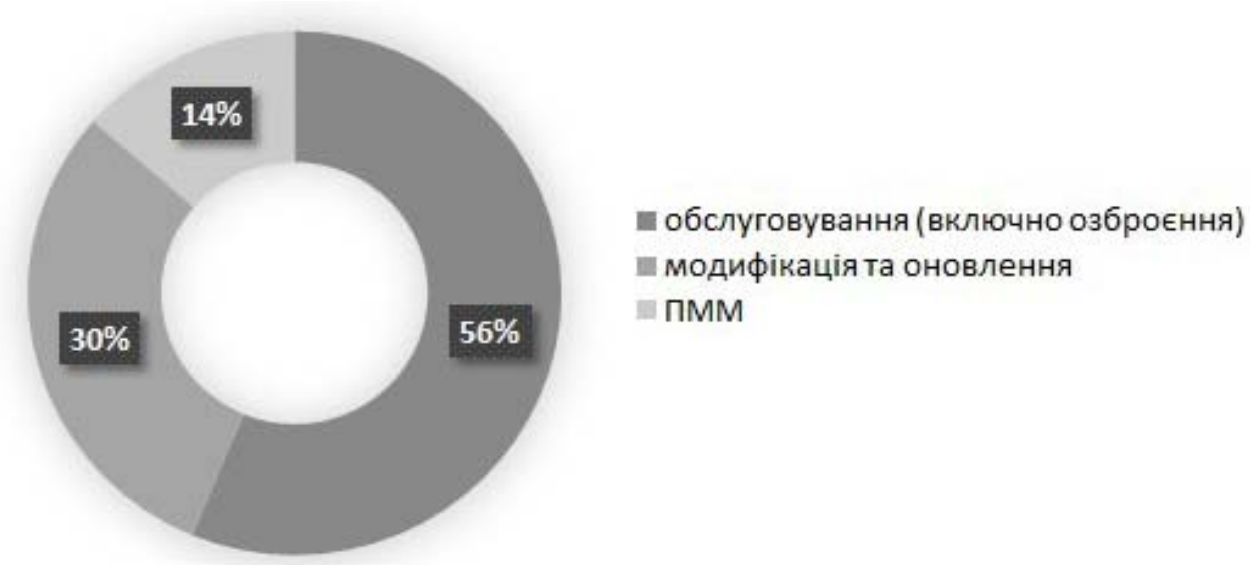

Рис. 3. Складові вартості ЖЦ бойової авіаційної техніки на стадії експлуатації Джерело: [13; 24-25].

Доцільно акцентувати, що витрати на експлуатацію літаків тактичної авіації формуються ще на етапі проектування літаків, тому навіть за оптимістичними прогнозами відповідних фахівців варіювання фінансовими витратами на стадії експлуатації літаків тактичної авіації можливо не більше ніж на 14-17\% від загальних експлуатаційних витрат [24]. На думку американських фахівців у галузі досліджень щодо розробки, випробувань, виробництва і модернізації, закупівлі та експлуатації озброєння та військової техніки, яких можна вважати “законодавцями мод” у галузі оцінювання життєвих циклів, в першу чергу систем ОВТ, витрати на забезпечення життєвих циклів ОВТ - свого роду “чорна діра" [26].

Застосування на практиці підходу щодо закупівлі ОВТ, що грунтується лише на оцінюванні вартості закупівлі ОВТ, та обирання такого експортеру OBT, що анонсує найменшу вартість закупівлі, є помилковою [12], оскільки експлуатація та підтримка найдешевшого ОВТ виявляється більш витратною, ніж експлуатація та підтримка більш дорожчого й, як наслідок, більш технологічного та досконалого ОВТ за весь період його експлуатації, який, наприклад, для літаків тактичної авіації складає близько 20-25 років [11].

Додатковим аргументом, що свідчить про необхідність проведення досліджень щодо комплексного оцінювання вартості ЖЦ носіїв спроможностей при формуванні довгострокових програм та планів розвитку системи ОВТ тактичної авіації ПС ЗС України, є доповідь Уилла Ропера, помічника Міністра Військово-Повітряних Сил (ВПС) США із закупівлі, технологій та логістики про оцінювання та прогнозування вартості життєвого циклу бойової авіаційної техніки, в якій наведено, що витрати на експлуатацію та обслуговування бойової авіаційної техніки із досягненням нею межі 15-ти річного терміну експлуатації щорічно зростають на 3-7\%. Але не зважаючи на це, планування довгострокових програм щодо розвитку та підтримання спроможностей ВПС США орієнтовано на закупівлю достатньо великих партій бойових літаків із розрахунком їх експлуатації не менш ніж на протязі 30 років. Аналогічна тенденція спостерігається серед більшості країн-членів НАТО [14-23; 25-28].

3 методичної точки зору, задача оцінювання вартості життєвих циклів систем ОВТ не є новою. Проведено достатньо великий обсяг досліджень щодо впровадження інформаційної підтримки життєвих циклів систем ОВТ та обгрунтування перспективного обрису системи ОВТ збройних сил, їх видів та родів військ. Але, не зважаючи на це, методичний апарат оцінювання вартості окремих стадій та етапів ЖЦ систем ОВТ при формуванні пропозицій до програмних документів довгострокового оборонного планування потребує вдосконалення в частині оцінювання фінансових показників носіїв спроможностей при розгляді питання щодо набуття певних спроможностей шляхом закупівлі нових зразків ОВТ та їх подальшої експлуатації та технічного супроводження [29-40].

Мета статті. 3 оглядом на вищенаведене, метою статті $є$ розробка методики прогнозування вартості життєвих циклів парків бойових літаків, як основних носіїв бойових спроможностей тактичної авіації Повітряних Сил Збройних Сил України.

\section{Виклад основного матеріалу}

За результатами попередньо проведених досліджень 3 обгрунтування напрямків розвитку методичного забезпечення формування раціональних програм розвитку системи ОВТ тактичної авіації ПС Збройних Сил України, а саме формування системи формалізованих критеріїв раціональності програми розвитку системи ОВТ тактичної авіації ПС ЗС України на довгостроковій перспективі, було обгрунтовано необхідність врахування вартості закупівлі 
одиниці серійного зразка тактичного винищувача $j$-го типу, який може розглядатися як альтернативний тип нової бойової авіаційної техніки для набуття необхідних спроможностей тактичною авіацією ПС ЗС України. Також обов'язковому врахуванню підлягає узагальнена вартість року експлуатації одного літака $j$-го типу.

Математичний вираз, що описує фінансову складову раціональної програми розвитку системи OBT тактичної авіації із урахуванням вартості закупівлі різнотипного парку тактичних літаків тактичної авіації та фінансових витрат на всьому терміні їх експлуатації, має наступний вигляд [41-46]:

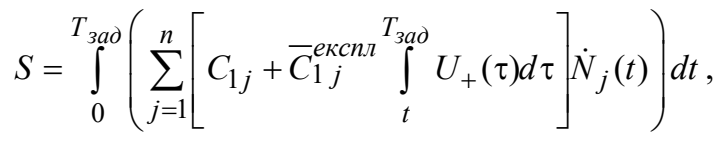

де $S$-загальні витрати ресурсів (у коштовногрошовому вигляді), що потрібні на закупівлю та експлуатацію літаків 3 моменту їх постачання у війська на всій глибині програмування $T_{\text {зад }}$;

$$
\dot{N}_{j}(t) \text { - похідна за часом кількості літаків } j \text {-го }
$$

типу $3 n$-альтернативних типів, що закуповуються, як функція від часу (розподіл закупівлі літаків за часом на періоді планування);

$C_{1 j}$ - вартість закупівлі одного літака $j$-го типу;

$\bar{C}_{1 j}^{\text {ексnл }}$ - узагальнена вартість року експлуатації одного літака $j$-го типу;

$U_{+}(\tau)$ - одинична асиметрична функція, така, що для поточного часу $\tau$ має вигляд: $U_{+}(\tau)=\left\{\begin{array}{l}0, \text { при } \tau<1 ; \\ 1, \text { при } \tau \geq 1,\end{array}\right.$ та яка характеризує момент початку несення експлуатаційних витрат після закупівлі літаків певної кількості літаків.

Для оцінювання вартості закупівлі одного літака $j$-го типу $C_{1 j}$ була розроблена математична модель вартості багатоцільових літаків тактичної авіації, які серійно виробляються, яка адекватно відображає залежність ціни сучасних та перспективних багатоцільових винищувачів на світовому ринку озброєнь від узагальнених показників їх якості. Такими показниками якості прийнято вважати коефіцієнти бойових потенціалів багатоцільових тактичних літаків при виконанні ними завдань щодо зни-

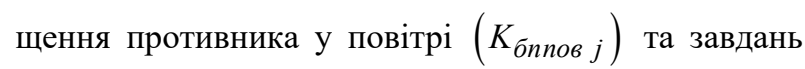
ураження наземних цілей $\left(K_{\text {бпназ } j}\right)$, визначених у єдиному еталоні, наприклад, в сучасному багатоцільовому винищувачі типу F-16E [44]. Названа математична модель вартості одного серійного літака, в цінах світового ринку озброєнь 2014 фінансового року, має наступний вигляд:

$$
\begin{gathered}
C_{1 j}=73,2+76,38 \cdot \ln \left(K_{\text {бппов } j}\right)+ \\
+15,28 \cdot \ln \left(K_{\text {бпназ } j}\right) \pm 4,2 .
\end{gathered}
$$

Узагальнену вартість експлуатації одного літака $j$-го типу $\bar{C}_{1 j}^{\text {експл }}$ можна розрахувати, виходячи із типового розподілу вартості ЖЦ літаків тактичної авіації та орієнтовних термінів їх експлуатації (рис. 1) за виразами [2-11]:

$$
\bar{C}_{1 j}^{\text {експл }}=\frac{C_{1 j} \cdot k_{3}}{\left(k_{1}+k_{2}\right) \cdot 100 \%},
$$

де $C_{1 j}$ - вартість закупівлі одного літака $j$-го типу;

$k_{1}, k_{2}$ - частка витрат в загальній вартості ЖЦ тактичного літака, що випадає на розробку та виробництво окремого зразка даного типу, відповідно;

$k_{3}$ - частка витрат в загальній вартості ЖЦ тактичного літака, що випадає на експлуатацію окремого зразка даного типу.

Для сучасних та перспективних бойових літаків тактичної авіації у відповідності до типового розподілу вартості ЖЦ по стадіях (рис. 1), офіційно прийнятого для використання та отриманого на основі узагальнення набутого досвіду створення та експлуатації бойових літаків тактичної авіації на світовому рівні, загальні витрати на експлуатацію та використання за призначенням окремого літака будуть пов'язані із вартістю серійного зразка наступним співвідношенням:

$$
\bar{C}_{1 j}^{\text {eекл }}=1,56 \cdot C_{1 j} .
$$

Щорічні узагальнені експлуатаційні витрати в межах прийнятих припущень можливо оцінити за допомогою виразу:

$$
\bar{C}_{1 j}^{\text {експл }}=\frac{1,56 \cdot C_{1 j}}{T_{j}^{\text {служ }},}
$$

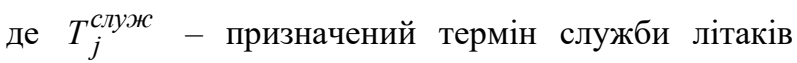
j-го типу (в роках).

Слід зазначити, що вираз (5) є актуальним у випадку розробки, виробництва бойової авіаційної техніки та ії постачання до власних збройних сил в межах однієї держави. У випадку, коли Україна, як і більшість країн світу, є імпортером бойової авіаційної техніки, вбачається доцільним брати до розгляду типовий (для цього випадку) розподіл вартості окремих етапів життєвого циклу (рис. 2).

Вартість експлуатації на рік одного екземпляру літака тактичної авіації за умови імпорту цього літака може визначатися у відповідності до типового розподілу вартості за окремими етапами життєвого циклу для бойової авіаційної техніки, що поставляється за імпортом. Так, питома вага витрат, в цьому випадку становить 28\% вартості всього ЖЦ - на закупівлю, а 72\% - на експлуатацію [12; 28]. 
Відповідно, щорічні витрати на експлуатацію одного літака для імпортованої бойової авіаційної техніки можуть бути оціненими за наступним виразом:

$$
\bar{C}_{1 j}^{\text {експл }}=\frac{2,57 \cdot C_{1 j}}{T_{j}^{\text {служ }} .}
$$

Таким чином, вираз (1) для оцінювання загальних витрат на закупівлю та експлуатацію нових тактичних літаків (із залишком строку служби рів-

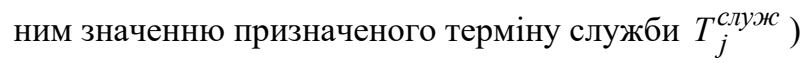
приймає наступний вигляд:

$$
S=\int_{0}^{T_{\text {зад }}}\left(\sum_{j=1}^{n}\left[1+\bar{C}_{1 j}^{\text {eксnл }} \int_{t}^{T_{3 а д}} U_{+}(\tau) d \tau\right] C_{1 j} \dot{N}_{j}(t)\right) d t .
$$

Необхідно зауважити, що вираз (7) є справедливим у випадку, якщо не звертати уваги на нерівномірний розподіл річної вартості експлуатації на всьому періоді даної стадії життєвого циклу, а користуватися осередненою річною вартістю використання та підтримки літака на всьому призначеному терміні його служби. В той же час, вбачається доцільним врахувати результати останніх досліджень щодо збільшення щорічних експлуатаційних витрат на бойові літаки, які перетнули межу 15-ти річного терміну експлуатації [12; 28].
Доцільність цього, як вже відмічалося вище, обгрунтовується оцінками Департаменту ВійськовоПовітряних Сил США та Коледжу оборонного менеджменту (Республіка Індія), відповідно до яких за кожні 10 років експлуатації після 15-ти річної експлуатації має місце майже дворазове збільшення щорічних витрат на експлуатацію одного імпортованого бойового літака. Відповідно цього, вартість експлуатації на рік одного екземпляру літака тактичної авіації, термін експлуатації якого перевищив 15 років, щорічно збільшується на 3-7\% [12; 28].

Врахування збільшення річної вартості експлуатації, яке відбиває відомий закон зміни інтенсивності відмов техніки з наближенням до призначених показників, особливо важливо для випадків, коли глибина планування розвитку системи озброєння тактичної авіації перевищуватиме 15 років, та/або об'єктом прогнозування витрат на експлуатацію є літаки, що закуповуються на вторинному ринку, тобто ті, що вже були в експлуатації.

Вираз (7) при врахуванні нерівномірного розподілу річної вартості експлуатації сучасних багатоцільових винищувачів та усередненні названої вартості лише на першій частині стадії експлуатації (тобто до 15 років) трансформується до наступного вигляду:

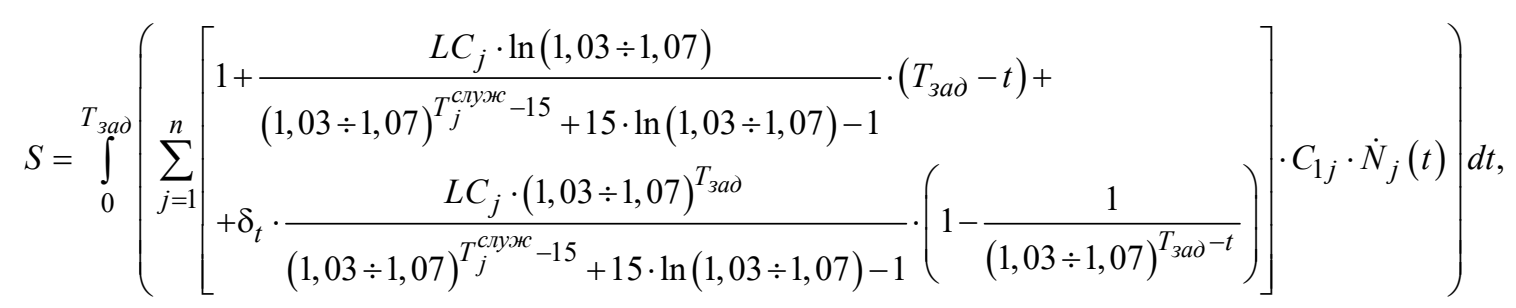

де $\delta_{t}(\tau)$ - допоміжний символ, що характеризує терміни експлуатації партії $N_{j k}$ літаків $j$-го типу, такий, що: $\delta_{t}(\tau)=\left\{\begin{array}{l}0, \text { якщо } T_{\text {зад }}-t \leq 15 \text { років; } \\ 1, \text { якщо } T_{\text {зад }}-t>15 \text { років; }\end{array}\right.$

$$
L C_{j} \text { - коефіцієнт, що відображає типовий роз- }
$$

поділ вартості ЖЦ в залежності від того чи були літаки $j$-го типу розроблені та вироблені всередині країни, або були закуплені за імпортом, такий, що:

$$
L C_{j}=\left\{\begin{array}{c}
1,56, \text { якщо літаки } j-\text { го типу } \\
\text { вироблені всередині країни; } \\
2,57, \text { якщо літаки } j-\text { го типу } \\
\text { закуплені за імпортом. }
\end{array}\right.
$$

При переході у виразі (8) від інтегралу за часом до кінцевих сум, вираз для оцінювання витрат на закупівлю та експлуатацію нових літаків, придбаних за імпортом на періоді планування $\left[0, T_{\text {зад }}\right]$, приймає вигляд:

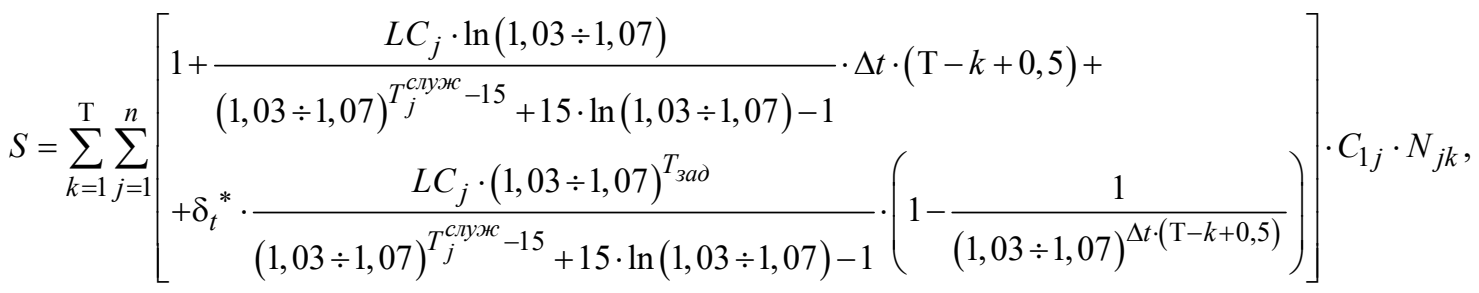

де $S$-загальні витрати ресурсів (у коштовногрошовому вигляді), що потрібні на закупівлю та експлуатацію парку нових літаків на глибині плану- вання $T_{\text {зад }}$;

$N_{j k}$ - кількість літаків кожного $j$-го типу $3 n$ - 
альтернативних типів, що закуповуються та починають використовуватися за призначенням в кожен $k$-й період часу на глибині планування $T_{\text {зад }}$;

$$
\delta_{t}^{*}(\tau) \text { - допоміжний символ, що характеризує }
$$
терміни експлуатації партії $N_{j k}$ літаків $j$-го типу, придбаних в $k$-й період часу, такий, що:

$$
\delta_{t}^{*}(\tau)=\left\{\begin{array}{l}
0, \text { якщо } \Delta t \cdot(\mathrm{T}-k+0,5) \leq 15 \text { років; } \\
1, \text { якщо } \Delta t \cdot(\mathrm{T}-k+0,5)>15 \text { років, }
\end{array}\right.
$$

де $T$ - кількість $k$ рівномірних відрізків-інтервалів, тривалістю $\Delta t$ кожен на глибині планування $\left[0, T_{\text {зад }}\right]$, тобто $T=\frac{T_{\text {зад }}}{\Delta t}$ (при цьому, вважається, що постачання нових літаків у війська на кожному інтервалі часу буде відбуватися у середні кожного інтервалу та нові літаки відразу після постачання у військові частини починають використовуватися за призначенням).

Отримані на основі проведеного аналізу співвідношення, які базуються на врахуванні та узагальнені набутого світового досвіду створення, закупівлі та експлуатації багатоцільових тактичних літаків, дозволяють розробити методику прогнозування вартості життєвого циклу парків альтернативних типів багатофункціональних літаків, як основних носіїв бойових спроможностей тактичної авіації, сутність якої наведена на рис. 4.

\section{Формування вихідних даних:}

•формування перелІку альтернативних типів багатоцільових тактичних літаків для закупівлі;

•значення коефіцієнтів бойового потенціалу обраних типів багатоцільових тактичних літаків у виконанні ними завдань знищення противника у повітрі та завдань ураження наземних цілей (якщо вони відсутні, можуть бути оцінені за існуючими методиками оцінювання коефіцієнтів бойового потенціалу із використанням відповідних кваліметричних моделей);

-ціна обраних типів багатоцільових тактичних літаків на світовому ринку озброєння (у разі відсутності інформації, оцінювання може бути проведено за математичною моделлю вартості одного серійного літака виду (2))

Прогноз щорічних витрат на експлуатацію літаків обраного типу у відповідност до розподілу вартості типового життєвого циклу бойових літаків:

-у разі оснащення збройних сил літаками, що розроблені та вироблені всередині країни:

$$
\bar{C}_{1 j}^{e \kappa n \imath}=\frac{1,56 C_{1 j}}{T_{j}^{c r y w}}
$$

•у разі оснащення збройних сил літаками, що постачаються до країни за імпортом:

$$
\bar{C}_{1 j}^{e \kappa n \pi}=\frac{2,57 C_{1 j}}{T_{j}^{c r y \varkappa}}
$$

$$
\begin{aligned}
& \text { Оцінювання зміни вартості ЖЦ парків альтернативних типів багатоцільових літаків }
\end{aligned}
$$

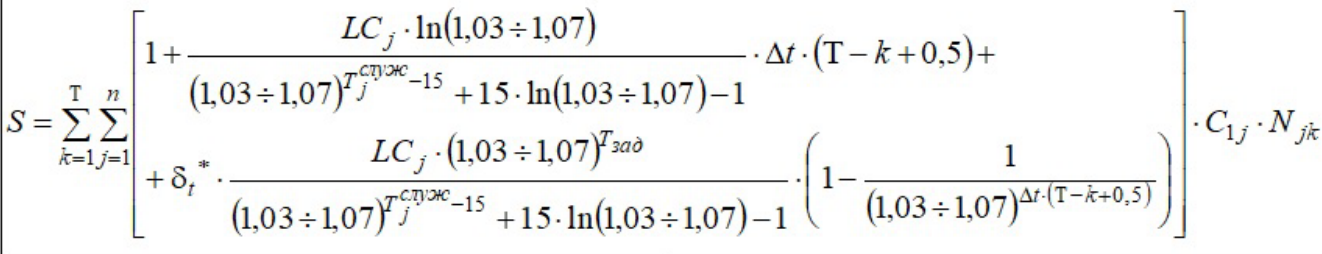

Рис. 4. Методика прогнозування вартості життєвого циклу парків альтернативних типів багатофункціональних літаків Джерело: розроблено авторами.

У разі розгляду літаків тактичної авіації, для яких $\epsilon$ невідомим значення коефіцієнтів бойового потенціалу, їх оцінювання має проводитися за існуючими методиками оцінювання коефіцієнтів бойового потенціалу із використанням відповідних ква- ліметричних моделей, як функціональних залежностей значень цих коефіцієнтів від значень тактикотехнічних характеристик цих літаків. Це дозволить за моделлю (2) розрахувати ціну одного тактичного літака на світовому ринку озброєнь. 
Наступним етапом застосування на практиці представленої методики $\epsilon$ оцінювання щорічних витрат на забезпечення закупленої бойової авіаційної техніки відповідними авіаційними засобами ураження, на організацію та здійснення інженерноавіаційного забезпечення та утриманням відповідної інфраструктури на всьому періоді їх експлуатації. В загальному випадку, зразки ОВТ, що постачаються до бойових частин, можуть бути розроблені та вироблені всередині країни, або закуплені за імпортом. Якщо укомплектування бойових частин здійснюється авіаційною технікою, що була розроблена та вироблена всередині країни, прогноз щорічних витрат на їх експлуатацію має здійснюватися за виразом (5). Якщо бойові літаки були закуплені за імпортом, прогноз щорічних витрат на їх експлуатацію має здійснюватися за виразом (6).

Заключним етапом застосування методики, що пропонується, є прогнозування вартості життєвого циклу парків альтернативних типів багатофункціональних літаків в залежності від їх ціни на світовому ринку озброєнь з урахуванням розподілу вартості типового життєвого циклу для бойової авіаційної техніки та зміни експлуатаційних витрат за часом експлуатації за виразом (9).

При заміні у виразі (9) змінних, що відповідають кількості $N_{j k}$-літаків $j$-го типу $3 n$-альтернативних типів в кожен $k$-й період часу на глибині програмування $T$ на відповідні невідомі змінні в математичній задачі синтезу раціональної програми розвитку системи ОВТ тактичної авіації [41-46], розроблена методика дозволяє інтегрувати іï до складу системного науково-методичного апарату з метою забезпечення формування цільової функції або виразів-обмежень в математичних задачах оптимізації програм оновлення парків бойових літаків.

\section{Висновки}

Таким чином, розроблено методику прогнозування вартості життєвого циклу парків альтернативних типів багатофункціональних літаків, як основних носіїв бойових спроможностей тактичної авіації Повітряних Сил Збройних Сил України. Методика базується на використанні залежності ціни серійних виробів тактичних літаків на світовому ринку озброєнь від значень узагальнених показників їх бойових властивостей, та вирізняється від відомих урахуванням розподілу вартості типового життєвого циклу для бойової авіаційної техніки, в тому числі, що закуповується за імпортом, а також урахуванням зміни експлуатаційних витрат за часом експлуатації.

Розроблена методика, окрім самостійного практичного значення, може бути інтегрованою в системний науково-методичний апарат синтезу раціональних програм розвитку системи ОВТ тактичної авіації на довгостроковій та середньостроковій перспективах. Це дозволить коректно, на основі використання накопиченого у світовій практиці досвіду експлуатації парків бойових тактичних літаків, формувати систему обмежень у математичній задачі оптимізації для синтезу раціональної програми розвитку системи ОВТ тактичної авіації ПС ЗС України.

Подальші дослідження будуть спрямовані на проведення оцінювання можливих витрат Державного бюджету України у разі закупівлі альтернативних типів літаків тактичної авіації у кількості, необхідній для забезпечення досягнення заданого рівня спроможностей.

\section{Список літератури}

1. Наказ Міністра оборони України “Сдиний перелік (каталог) спроможностей Міністерства оборони України, Збройних Сил України та інших складових сил оборони № 7983/в/36 від 09.12.2019”. - К.: Міністерство оборони України, 2019. -618 с.

2. Офіційний сайт MIL.GOV. Рекомендації з оборонного планування на основі спроможностей. - Режим доступу: https://www.mil.gov.ua/content/other/ Recommendationson_CBP_120617.pdf.

3. Візія Повітряних Сил 2035. - Вінниця: Командування Повітряних Сил Збройних Сил України, 2020. - 42 с.

4. Official Site GAO.GOV. United States Government Accountability Office weapon system sustainment. Report to Congressional Committees. - Available at: https://www.gao.gov/assets/700/694408.pdf.

5. Raphael S. Cohen Air Force Strategic Planning [Electronic resource] / S. Raphael // RAND Corporation. - 2017. - 96 p. - Available at: https://www.rand.org/pubs/research_reports/RR1765.html.

6. Methods and Models for Life Cycle Costing [Electronic resource]. - 2007. - 226 p. - Available at: https://www.sto.nato.int/publications/STO\%20Technical\%20Reports/RTO-TR-SAS-054/\$\$TR-SAS-054-ALL.pdf.

7. Семон Б.Й. Сучасний метод бойових потенціалів в прикладних задачах планування розвитку та застосування тактичної авіації: монографія / Б.Й. Семон, О.Б. Леонтьєв. - К.: НАОУ, 2009. - 336 с.

8. Сумин А.С. Военная экономика: управление, военно-экономическая безопасность / А.С. Сумин, Ю.Н. Арепин. М.: Воениздат, 1995. - 183 с.

9. Демидов Б.А. Методы военно-экономического анализа / Б.А. Демидов. - Х.: ВИРТА ПВО, 1985. - 619 с.

10. Саркисян С.А. Экономика авиационной промышленности / С.А. Саркисян. - М.: Машиностроение, 1986. - 352 с.

11. Офіційний сайт GOV.UA. Методичні рекомендації з фінансово-економічного обгрунтування вартості повного життєвого циклу спроможностей 3 урахуванням принципів і стандартів НАТО. - Режим доступу: https://www.mil.gov.ua/content/oboron_plans/metod_recom_z_fin_ekon_life_ciklu_nato.pdf.

12. Life-Cycle Cost (LCC): Concept Yet To Take Shape. Defence Production and Acquisition Business News [Electronic 
resource]. - Available at: https://defproac.com/?p=2125.

13. Fiscal Analysis of the Interim F-18 Aircraft [Electronic resource]. - Ottawa: Parliamentary Budget Officer, 2019. 31 p. - Available at: https://www.pbo-dpb.gc.ca/web/default/files/Documents/Reports/2019/F-18/CF_18_Report_EN.pdf.

14. Morocco - F-16 block 52+ upgrade to F-16v configuration [Electronic resource]. - Available at: https://www.dsca.mil/press-media/major-arms-sales/morocco-f-16-block-52-upgrade-f-16v-configuration.

15. Офіційний сайт MOD.GOV. Najväšší modernizačný projekt ozbrojených síl v histórii sa stáva realitou, minister obrany podpísal zmluvy $\mathrm{k}$ obstaraniu lietadiel F-16. - Режим доступу: https://www.mod.gov.sk/43306-sk/najvacsimodernizacny-projekt-ozbrojenych-sil-v-historii-sa-stava-realitou-minister-obrany-podpisal-zmluvy-k-obstaraniu-lietadiel-f-16/.

16. Gulf Countries, US Must Boost 4th \& 5th Fifth Gen Fighter Data Sharing [Electronic resource]. - Available at: https://breakingdefense.com/2020/12/gulf-countries-us-must-boost-4th-5th-fifth-gen-fighter-data-sharing/.

17. Contracts For April 2, 2020 Lockheed Martin Aeronautics, Ft. Worth, Texas, has been awarded a $\$ 512,004,418$ firmfixed-price contract for F-16 Block 70 production for the Republic of Bulgaria [Electronic resource]. - Available at: https://www.defense.gov/Newsroom/Contracts/Contract/Article/2135175/\#LOCKHEED040220.

18. Офіційний сайт EUROINTEGRATION.COM. Бельгия выберет американский F-35, а не европейский истребитель для замены своих самолетов. - Режим доступу: https://www.eurointegration.com.ua/rus/news/2018/10/22/7088477/.

19. Офіційний сайт ARMYINFORM.COM. Як різні країни оновлюють свої бойові авіапарки. - Режим доступу: https://armyinform.com.ua/2020/11/yak-rizni-krayiny-onovlyuyut-svoyi-bojovi-aviaparky/.

20. Офіційний сайт AIRFORCEMAG. COM. Greece Wants F-35s So Quickly It's Willing to Accept Used Aircraft. Available at: https://www.airforcemag. com/greece-wants-f-35s-so-quickly-its-willing-to-accept-used-aircraft/.

21. Программа закупки Румынией истребителей F-16: состояние и перспективы [Електронний ресурс]. - Режим доступу: https://bmpd.livejournal.com/2385586.html.

22. Greece equips itself with the RAFALE in the continuity of a partnership with dassault aviation of more than 45 years [Electronic resource]. - Available at: https://www.dassault-aviation.com/en/group/press/press-kits/greece-equips-itself-with-therafale-in-the-continuity-of-a-partnership-with-dassault-aviation-of-more-than-45-years/.

23. Senate to vote on banning $\$ 23$ billion UAE arms sales next week [Electronic resource]. - Available at: https://www.defensenews.com/congress/2020/12/03/us-senate-to-vote-next-week-on-23b-uae-arms-sale/?utm_source=

Sailthru\&utm_medium=email\&utm_campaign=EBB\%2012.04.20\&utm_term=Editorial\%20-\%20Early\%20Bird\%20Brief.

24. The official site HELLENIC AIR FORCE GENERAL STAFF. A Life Cycle Cost Approach For Military Aviation. Available at: https://www.haf.gr/wp-content/uploads/2016/02/Life-Cycle-Cost.pdf.

25. Bunecke K. Evaluating annual fixed wing: Maintenance Costs / K. Bunecke // Defense A R Journal. - 2018. - № 3(25). - P. 244.

26. Ходаренок М. “Нечто волшебное”: США испытали истребитель будущего [Електронний ресурс] / М. Ходаренок. - Режим доступу: https://www.gazeta.ru/army/2020/09/16/13253143.shtml.

27. The official site AF.MIL. United States Air Force. - Available at: https://www.af.mil/About-Us/Biographies/ Display/Article/1467795/dr-will-roper/.

28. Roper W. There is No Spoon: The New Digital Acquisition Reality [Electronic resource] / W. Roper. - 2010. - 19 p. Available at: https://software.af.mil/wp-content/uploads/2020/10/There-Is-No-Spoon-Digital-Acquisition-7-Oct-2020-digitalversion.pdf.

29. Руснак І.С. Розвиток методологічних положень обгрунтування заходів організаційного будівництва (реформування) Повітряних Сил ЗС України / І.С. Руснак, О.М. Загорка // Наука і оборона. - 2010. - № 1. - С. 6-12.

30. Чепков І.Б. Основні аспекти методології формування та супроводження реалізації середньострокових програм озброєння в умовах особливого періоду / І.Б. Чепков, М.І. Луханін, І.В. Борохвостов // Озброєння та військова техніка. 2016. - № 4(2). - C. 3-8.

31. Оборонна реформа: системний підхід до оборонного менеджменту: монографія / А. Павліковський, В. Фролов, Ф. Саганюк та ін.; за заг. ред. А. Сиротенка. - К.: НУОУ, 2020. - 274 с.

32. Оборонний огляд: український вимір 2014-2018: монографія / Ф. Саганюк, А. Павліковський, П. Щипанський та ін.; за заг. ред. І. Руснака. - К.: МО та ГШ ЗС України, НУОУ, 2019. - 196 с.

33. Борохвостов І.В. Визначення критеріїв та методів оцінювання шляхів забезпечення військових формувань озброєнням та військовою технікою / І.В. Борохвостов, М.О. Білокур // Озброєння та військова техніка. - 2018. № 3(19). - С. 3-8.

34. Бадрак В.В. Переозброєння Збройних Сил України: раціоналізація підходів, пошук альтернативних шляхів / В.В. Бадрак // Озброєння та військова техніка. - 2016. - № 1(9). - С. 3-8.

35. Системно-концептуальні положення й організаційно-методичні основи обгрунтування, вибору і реалізації обрису перспективної системи озброєння протиповітряної оборони держави та їі збройних сил / О.В. Турінський, Б.О. Демідов, Д.А. Гриб, О.О. Хмелевська // Системи озброєння і військова техніка. - 2019. - № 2(58). - С. 55-69. https://doi.org/10.30748/soivt.2019.58.08.

36. Методичний підхід щодо підвищення ефективності виконання заходів програм розвитку збройних сил України шляхом раціонального розподілу фінансових ресурсів на них / О.І. Кремешний, Р.В. Бойко, О.М. Семененко, І.М. Чернишова // Збірник наукових праць Харківського університету Повітряних Сил. - 2012. - № 2(31). - С. 19-23.

37. Формування порядку воєнно-економічного оцінювання результатів виконання заходів та програм розвитку Збройних Сил України / Р.В. Бойко, О.М. Семененко, О.І. Кремешний, І.М. Чернишова // Системи озброєння і військова техніка. - 2011. - № 3(27). - С. 98-101. 
38. Метод оцінювання ефективності виконання програм (планів) розвитку збройних сил України з урахуванням повноти та своєчасності їх фінансування / О.М. Семененко, О.Г. Водчиць, Л.М. Семененко, Р.В. Бойко, Д.В. Башинський, Г.Г. Зубрицька // Збірник наукових праць Харківського національного університету Повітряних Сил. - 2017. № 2(51). - С. 51-58.

39. Методичний підхід до визначення бойового складу збройних сил воєнного і мирного часу / О.М. Загорка, B.М. Можаровський, В.С. Фролов, I.О. Загорка // Збірник наукових праць Центру воєнно-стратегічних досліджень Національного університету оборони України ім. І. Черняховського. - 2019. - № 1(65). - С. 6-11.

40. Теорія озброєння. Науково-технічні проблеми та завдання. Воєнно-економічний аналіз життєвого циклу озброєння та військової техніки: теоретикометодологічні засади: монографія / І.Б. Чепков, В.В. Зубарєв, В.К. Борохвостов та ін. - К.: ВД Дмитра Бураго, 2018. - 475 с.

41. Леонтьєв О.Б. Напрями удосконалення науково-методичного апарату обгрунтування основних напрямів розвитку системи озброєння авіації Повітряних Сил Збройних Сил України / О.Б. Леонтьєв, М.В. Науменко // Наука і техніка Повітряних Сил Збройних Сил України. - 2020. - № 3(40). - С. 69-78. https://doi.org/10.30748/nitps.2020.40.08.

42. Дроздов С.С. Формалізовані критерії раціональності програми розвитку системи озброєння тактичної авіації Повітряних Сил Збройних Сил України на довгостроковій перспективі (прогнозованій) загрозі / С.С. Дроздов, О.Б. Леонтьєв, М.В. Науменко // Збірник наукових праць Харківського національного університету Повітряних Сил. 2020. - № 3(65). - С. 13-24. https://doi.org/10.30748/zhups.2020.65.02.

43. Дроздов С.С. Методичний підхід до розв'язування математичної задачі синтезу раціональної програми розвитку системи озброєння тактичної авіації на основі критерію мінімізації фінансових витрат за умови досягнення необхідних бойових спроможностей / С.С. Дроздов, О.Б. Леонтьєв, М.В. Науменко // Наука і техніка Повітряних Сил Збройних Сил України. - 2020. - № 4(41). - С. 54- 63. https://doi.org/10.30748/nitps.2020.41.06.

44. Леонтьєв О.Б. Методичний підхід до розв'язування математичної задачі синтезу раціональної програми розвитку системи озброєння тактичної авіації на основі критерію досягнення максимально можливого рівня бойових спроможностей за умови обмеженого ресурсного забезпечення / О.Б. Леонтьєв, М.В. Науменко // Наука і техніка Повітряних Сил Збройних Сил України. - 2021. - № 1(42). - С. 50-60. https://doi.org/10.30748/nitps.2021.42.06.

45. Науменко М.В. Математична модель темпу серійного виробництва багатоцільових літаків тактичної авіації / М.В. Науменко // Збірник наукових праць Харківського національного університету Повітряних Сил. - 2021. - № 1(67). - C. 47-57. https://doi.org/10.30748/zhups.2021.67.06.

46. Науменко М.В. Удосконалена математична модель вартості багатоцільових тактичних винищувачів / М.В. Науменко // Системи озброєння і військова техніка. - 2021. - № 1(65). - С. 98-106. https://doi.org/10.30748/soivt.2021.65.14.

Надійшла до редколегії 22.02.2021

Схвалена до друку 13.04.2021

\section{Відомості про авторів:}

\section{Леонтьєв Олексій Борисович} доктор технічних наук професор головний науковий співробітник Харківського національного університету Повітряних Сил ім. І. Кожедуба, Харків, Україна https://orcid.org/0000-0003-4003-7759

\section{Науменко Марина Володимирівна} кандидат технічних наук старший науковий співробітник докторант Харківського національного університету Повітряних Сил ім. І. Кожедуба, Харків, Україна https://orcid.org/0000-0002-1216-9263

\section{Information about the authors:}

Oleksii Leontiev

Doctor of Technical Sciences Professor

Chief Research

of Ivan Kozhedub Kharkiv

National Air Force University,

Kharkiv, Ukraine

https://orcid.org/0000-0003-4003-7759

\author{
Maryna Naumenko \\ Candidate of Technical Sciences Senior Research \\ Doctoral Student \\ of Ivan Kozhedub Kharkiv \\ National Air Force University, \\ Kharkiv, Ukraine \\ https://orcid.org/0000-0002-1216-9263
}

\title{
МЕТОДИКА ПРОГНОЗИРОВАНИЯ СТОИМОСТИ ЖИЗНЕННОГО ЦИКЛА ПАРКОВ АЛЬТЕРНАТИВНЫХ ТИПОВ НОВЫХ МНОГОЦЕЛЕВЫХ САМОЛЕТОВ, КАК ОСНОВНЫХ НОСИТЕЛЕЙ БОЕВЫХ СПОСОБНОСТЕЙ ТАКТИЧЕСКОЙ АВИАЦИИ
}

\author{
А.Б. Леонтьев, М.В. Науменко
}

При формировании долгосрочных программ развития системы вооружения и военной техники тактической авиаичи Воздушных Сил Вооруженных Сил Украины, которая должна осуществляться на основе формализованных критериев типа “эффективность - стоимость - время", одной из важных составляюших является прогнозирование финансовых затрат на закупку и поставку в войска необходимого количества многоцелевых самолетов тактической авиачии, а также расходов на обеспечение соответствующим вооружением, на содержание соответствующей инфраструктуры на всем периоде их эксплуатации и на осуществление мероприятий инженерно-авиационного обеспечения. Пред- 
ставленная методика прогнозирования стоимости жизненного ијикла парков многоцелевых самолетов направлена на обеспечение корректного формирования системы ограничений в математической задаче оптимизачии для синтеза рациональной программы развития системы вооружения и военной техники тактической авиации Воздушных Сил Вооруженных Сил Украины. Разработанная методика прогнозирования стоимости жизненного цикла парков многоцелевых самолетов, которые рассматриваются как основные носители боевых возможностей тактической авиации Воздушных Сил Вооруженных Сил Украины, основывается на использовании зависимости цены серийных тактических самолетов на мировом рынке вооружений от значений обобщенных показателей их боевых свойств. Особенностью предлагаемой методики является учет стоимости жизненного ијила парков альтернативных типов многоцелевых самолетов тактической авиации в зависимости от того, есть ли самолеты, которые планируются к поставке в боевые части разработанными и произведенным внутри страны или будут закуплены по импорту. Это вносит различия в типовое распределение стоимости по стадиям и этапам жизненного цикла боевой авиачионной техники, которые должны быть учтены. Также в представленной методике предусмотрен учет изменения затрат на эксплуатаиию боевых самолетов, срок эксплуатации которых будет превымать 15 лет.

Ключевые слова: планирование на основе возможностей, научно-методический аппарат, жизненный ичикл авиаиионной техники, типовое распределение стоимости жизненного ичикла, система вооружения авиации Воздушных Сил Вооруженных Сил Украины.

\title{
METHODS FOR PREDICTING THE COST OF THE LIFE CYCLE OF PARKS OF ALTERNATIVE TYPES OF MULTIPURPOSE NEW AIRCRAFT AS THE MAIN CARRIERS OF THE BATTLE ABILITY OF TACTICAL AVIATION
}

\author{
O. Leontiev, M. Naumenko
}

When forming long-term programs for the development of the system of weapons and military equipment of tactical aviation of the Air Force of the Armed Forces of Ukraine, which should be carried out on the basis of formalized criteria of the "efficiency - cost - time" type, one of the important components is the forecasting of financial costs for the purchase and delivery of the required amount to the troops. multipurpose tactical aircraft, as well as the costs of providing the appropriate weapons, the maintenance of the appropriate infrastructure throughout the entire period of their operation and the implementation of aviation engineering support measures. The presented methodology for predicting the life cycle cost of multipurpose aircraft fleets is aimed at ensuring the correct formation of a system of constraints in the mathematical optimization problem for the synthesis of a rational program for the development of the weapons system and military equipment of tactical aviation of the Air Force of the Armed Forces of Ukraine. The developed methodology for predicting the cost of the life cycle of multipurpose aircraft fleets, which are considered as the main carriers of the combat capabilities of tactical aviation of the Air Force of the Armed Forces of Ukraine, is based on the use of the dependence of the price of serial tactical aircraft on the world arms market on the values of generalized indicators of their combat properties. A feature of the proposed methodology is taking into account the cost of the life cycle of the fleets of alternative types of multipurpose tactical aircraft, depending on whether there are aircraft that are planned to be delivered to warheads designed and produced domestically or will be imported. This introduces differences in the typical distribution of the cost over the stages and stages of the life cycle of military aircraft, which must be taken into account. Also, the presented methodology provides for accounting for changes in the operating costs of combat aircraft, the service life of which will exceed 15 years.

Keywords: capability-based planning, scientific and methodological apparatus, life cycle of aviation equipment, typical distribution of life cycle cost, System of the Air Force of the Armed Forces of Ukraine. 